https://doi.org/10.15407/ujpe63.3.238

V.V. PROROK, O.I. DACENKO, L.A. BULAVIN, S.E. ZELENSKY, L.V. POPERENKO

Kyiv National Taras Shevchenko University, Faculty of Physics

(2, Prosp. Academician Glushkov, Kyiv 03022, Ukraine; e-mail: prorok@univ.kiev.ua)

\title{
INVESTIGATION OF MECHANISMS OF POTASSIUM AND CESIUM-137 UPTAKE BY PLANTS WITH OPTICAL AND GAMMA SPECTROMETRIES IN THE FIELD UNDER WATER-STRESSED CONDITIONS
}

\section{Introduction}

There is always the possibility of an accident "a la Chornobyl" or "a la Fukusima" for all countries with nuclear power stations. Moreover, soil may be polluted with radionuclides from other sources. So, the problem of the prediction of the ${ }^{137} \mathrm{Cs}$ concentration in plants from contaminated land with certain type of soil is actual for any country and, to a greater extent, for those with a significant agrarian part in the economy.

Cesium, which is not required by plants, is taken up from the soil solution by various cation trans-

(C) V.V. PROROK, O.I. DACENKO, L.A. BULAVIN, S.E. ZELENSKY, L.V. POPERENKO, 2018 porters in the plasma membrane of root cells [13]. By contrast, potassium is an essential plant nutrient. The nonselective cation channels (NSCCs) generally show a low selectivity between $\mathrm{Cs}$ and $\mathrm{K}$. It has been demonstrated that NSCCs mediate most of the cesium uptake by root cells in potassium-replete plants, but that $\mathrm{K} / \mathrm{H}$-symporters mediate most of the cesium uptake by root cells in potassium-deficient plants [4-7]. Nonselective cation channels in plants are described in Ref. [8].

The inward-rectified K-channel (KIRC) as a lowaffinity transport system generally has a high selectivity for $\mathrm{K}$ versus $\mathrm{Cs}$ and contributes little to the cesium uptake by root cells under typical soil conditions [1, 3, 4]. A high-affinity system catalyzes most

ISSN 2071-0194. Ukr. J. Phys. 2018. Vol. 63, No. 3 
of the potassium uptake in potassium-deficient plants and at submillimolar potassium concentrations in the rhizosphere solution $[9,10]$.

The NSCC (passive) is dominant at millimolar potassium external concentrations, and the high-affinity system is dominant at micromolar potassium external concentrations $[11,12]$. The cross-over point defining the potassium external concentration either side of which one of the systems assumes dominance has been shown to be in the range from 0.3 to $1 \mathrm{mM}$ [1].

It was concluded in Refs. [6, 13] after investigations of Arabidopsis that Cs is transferred to the plant via voltage-nonsensitive cation channels at a potassium depletion. If there is a potassium starvation of the plant, the essential part of the Cs transfer to the plant is via $\mathrm{K}^{+} / \mathrm{H}^{+}$transporters.

It was affirmed in Ref. [2] that the Cs transfer to plants occurs only via the potassium transport system, i.e., the $\mathrm{K}^{+} / \mathrm{H}^{+}$transporter and potassium channels. There is a slight discrimination against Cs if the external potassium concentration is less than $0.3 \mathrm{mM}$, and there is a strong discrimination against Cs if the external potassium concentration is more (potassium channels are prevailing).

The above-mentioned investigations were performed under artificial conditions. These results could be not applicable to the plants grown under native conditions.

A theoretical model of the effect of potassium on the uptake of radiocesium by rice was proposed in Ref. [14] after pot and field experiments.

It was suggested in Refs. [15, 16] after the experiment under field conditions that the dissolved potassium per unit of soil volume $\left(C_{\mathrm{K}}\right)$ as the amount of potassium available to a plant determines the selectivity of ${ }^{137} \mathrm{Cs}$ and potassium accumulation by plants in the field, rather than potassium concentration in the soil solution. In those studies, $C_{\mathrm{K}}$ was always above $0.5 \mu \mathrm{g} / \mathrm{cm}^{3}$. However, no experiments were done for less $C_{\mathrm{K}}$, which is usually an attribute of water-stress conditions. In this work, the use of ion channels by plants under different field conditions including the hard deficit of the dissolved potassium in soil $\left(C_{\mathrm{K}}\right.$ is below $\left.0.5 \mu \mathrm{g} / \mathrm{cm}^{3}\right)$ is investigated.

\section{Experiment}

We studied the growth of different plants at three experimental field sites with different types of soil in the $10-\mathrm{km}$ Exclusion Zone of the Chernobyl Nu- clear Power Plant: i) site B $\left(51^{\circ} 22^{\prime} 33.6^{\prime \prime} \mathrm{N}, 29^{\circ} 54^{\prime} 5.1^{\prime \prime}\right.$ E) with a sandy-loam soil, the pollution by Cs-137 was about $1.7 \times 10^{4} \mathrm{~Bq} / \mathrm{kg}$, gamma background was $380 \mu \mathrm{Rh} / \mathrm{h}$, and soil density was $1.41 \mathrm{~g} / \mathrm{cm}^{3}$; ii) site B2 $\left(51^{\circ} 22^{\prime} 29.5^{\prime \prime} \mathrm{N}, 29^{\circ} 54^{\prime} 6.3^{\prime \prime} \mathrm{E}\right)$ with a sandy soil, the pollution by Cs- 137 was about $1.1 \times 10^{4} \mathrm{~Bq} / \mathrm{kg}$, gamma background was $350 \mu \mathrm{Rh} / \mathrm{h}$, and soil density was $1.42 \mathrm{~g} / \mathrm{cm}^{3}$; and iii) site D $\left(51^{\circ} 22^{\prime} 29.2^{\prime \prime} \mathrm{N}\right.$, $\left.29^{\circ} 54^{\prime} 0.1^{\prime \prime} \mathrm{E}\right)$ with a peaty soil, the pollution by Cs137 was about $1.5 \times 10^{4} \mathrm{~Bq} / \mathrm{kg}$, gamma background was $200 \mu \mathrm{Rh} / \mathrm{h}$, and soil density was $0.85 \mathrm{~g} / \mathrm{cm}^{3}$.

Rapidly maturing plants distinguishable one from another as possible were mixed together and sowed at the sites B, B2, D. These were radish (Raphanus sativus), mustard (Sinapis sp.), lettuce (Lactuca sativa), spinach (Spinacia oleracea), beet (Beta vulgaris), coriander (Coriandrum sativum), watercress (Lepidium sativum), and valerianella locusta (Valerianella locusta).

The plants were sowed (and then harvested) simultaneously at each experimental site several times during each season. No artificial moisturizing of soils at the sites was done in the experiment. We selected the samples several times each season as in Refs. [16,17]. Every time, we harvested samples of the soils, sowed plants if they had grown, as well as some kinds of wild plants grown within the site areas. These were couch grass (Elytrigia repens), lady'sthumb (Persicaria maculosa), berteroa (Berteroa incana L.), bunias (Bunias orientalis L.), ground-ivy (Glecoma hederacea), pansy (Viola tricolor), common sorrel (Rumex acetosa), st. John's wort (Hypericum), common orach (Atriplex patula), evening primrose (Oenothera rubricaulis), bindweed (Convolvulus), and yellow-foxtail grass (Setaria glauca). As a rule, we selected whole plants. We harvested all the grown plants at each experimental site at each sample selection. But we did not harvest sprouts of plants, so they could continue to grow. The mass of each kind of selected plants was within 5-500 g. The plants were sampled before blossoming and were washed and dried. Soil solutions were extracted from soil by an OS-6M centrifuge (USSR) with a frequency of $6000 \mathrm{rpm}$ for $15 \mathrm{~min}$. The soil solution was extracted immediately if the humidity was enough. If the sample of soil was too dry for the extraction, we added distilled water to the sample and centrifuged 12 hours later. It was shown [18] that the addition of even a low amount of water to some soils significantly changes 
Table 1. Parameters of plant and soil samples for site D (peaty soil)

\begin{tabular}{|c|c|c|c|c|c|c|}
\hline$h$ & Date & Sample & $\mathrm{K}, \mathrm{mg} / \mathrm{g}$ & ${ }^{137} \mathrm{Cs}, \mathrm{Bq} / \mathrm{kg}$ & $\left({ }^{137} \mathrm{Cs} / \mathrm{K}\right)_{p} /\left({ }^{137} \mathrm{Cs} / \mathrm{K}\right)_{s s}$ & $C_{\mathrm{K}}, \mathrm{mg} / \mathrm{cm}^{3}$ \\
\hline 0.139 & 28.05 .2012 & $\begin{array}{l}\text { Soil solution } \\
\text { Raphanus sativus }\end{array}$ & $\begin{array}{l}0.0084 \\
31.2\end{array}$ & $\begin{array}{l}8.52 \\
4108\end{array}$ & 0.130 & 0.99 \\
\hline 0.208 & 25.06 .2012 & $\begin{array}{l}\text { Soil solution } \\
\text { Elytrigia repens } \\
\text { Sinapis sp. } \\
\text { Persicaria maculosa } \\
\text { Raphanus sativus } \\
\text { Lactuca sativa } \\
\text { Spinacia oleracea } \\
\text { Beta vulgaris } \\
\text { Coriandrum sativum }\end{array}$ & $\begin{array}{l}\quad 9.1 \\
21.26 \\
42.52 \\
38.39 \\
32.12 \\
69.6 \\
66 \\
52.9 \\
48.5\end{array}$ & $\begin{array}{l}6.01 \\
1690 \\
7251 \\
2752 \\
11446 \\
3400 \\
270 \\
11000 \\
1700\end{array}$ & $\begin{array}{l}0.120 \\
0.259 \\
0.109 \\
0.539 \\
0.073 \\
0.006 \\
0.315 \\
0.053\end{array}$ & 1.61 \\
\hline 0.358 & 18.09 .2012 & $\begin{array}{l}\text { Soil solution } \\
\text { Raphanus sativus } \\
\text { Berteroa incana L. } \\
\text { Glecoma hederacea } \\
\text { Persicaria maculosa }\end{array}$ & $\begin{array}{l}0.0075 \\
42.6 \\
28 \\
27.3 \\
30.8\end{array}$ & $\begin{array}{l}5.21 \\
13870 \\
7156 \\
6188 \\
2560\end{array}$ & $\begin{array}{l}0.470 \\
0.369 \\
0.326 \\
0.120\end{array}$ & 2.28 \\
\hline 0.252 & 15.05 .2013 & $\begin{array}{l}\text { Soil solution } \\
\text { Viola tricolor } \\
\text { Elytrigia repens } \\
\text { Rumex acetosa } \\
\text { Hypericum }\end{array}$ & $\begin{array}{l}0.004 \\
31.76 \\
18.38 \\
37.79 \\
16.31\end{array}$ & $\begin{array}{c}2.32 \\
3514 \\
1957 \\
4500 \\
865\end{array}$ & $\begin{array}{l}0.191 \\
0.184 \\
0.205 \\
0.091\end{array}$ & 0.856 \\
\hline 0.345 & 04.06 .2013 & $\begin{array}{l}\text { Soil solution } \\
\text { Raphanus sativus } \\
\text { Lepidium sativum }\end{array}$ & $\begin{array}{l}0.0094 \\
31.84 \\
42.81\end{array}$ & $\begin{array}{l}2.64 \\
12047 \\
6130\end{array}$ & $\begin{array}{l}1.347 \\
0.510\end{array}$ & 2.75 \\
\hline 0.173 & 26.06 .2013 & $\begin{array}{l}\text { Soil solution } \\
\text { Coriandrum sativum } \\
\text { Persicaria maculosa } \\
\text { Beta vulgaris } \\
\text { Atriplex patula } \\
\text { Raphanus sativus }\end{array}$ & $\begin{array}{c}8 \\
20.71 \\
21.81 \\
41.91 \\
52.72 \\
26.23\end{array}$ & $\begin{array}{l}4.89 \\
2851 \\
15347 \\
33366 \\
10888 \\
17893\end{array}$ & $\begin{array}{l}0.225 \\
1.151 \\
1.302 \\
0.338 \\
1.116\end{array}$ & 1.176 \\
\hline 0.0772 & 09.07 .2013 & $\begin{array}{l}\text { Soil solution } \\
\text { Raphanus sativus } \\
\text { Beta vulgaris } \\
\text { Lactuca sativa } \\
\text { Atriplex patula } \\
\text { Coriandrum sativum } \\
\text { Lepidium sativum }\end{array}$ & $\begin{array}{l}0.0075 \\
26.86 \\
32.87 \\
21.8 \\
54.35 \\
17.15 \\
26.1\end{array}$ & $\begin{array}{l}1.85 \\
29383 \\
40829 \\
13662 \\
12454 \\
3994 \\
26000\end{array}$ & $\begin{array}{l}4.435 \\
5.036 \\
2.541 \\
0.929 \\
0.944 \\
4.038\end{array}$ & 0.492 \\
\hline 0.0718 & 20.08 .2013 & $\begin{array}{l}\text { Soil solution } \\
\text { Atriplex patula } \\
\text { Valerianella locusta } \\
\text { Raphanus sativus } \\
\text { Coriandrum sativum } \\
\text { Oenothera rubricaulis }\end{array}$ & $\begin{array}{l}0.0049 \\
30.5 \\
11.9 \\
7.38 \\
7.31 \\
10.25\end{array}$ & $\begin{array}{l}2.52 \\
15255 \\
11663 \\
32222 \\
4409 \\
12063\end{array}$ & $\begin{array}{l}0.965 \\
1.890 \\
8.420 \\
1.163 \\
2.270\end{array}$ & 0.297 \\
\hline
\end{tabular}

the content of ${ }^{137} \mathrm{Cs}$ in a soil solution. We selected the sites with soils, for which the ${ }^{137} \mathrm{Cs}$ concentration in their solutions was not changed with the ad- dition of a little of water. As a rule, we obtained near $200 \mathrm{ml}$ of a soil solution at each extraction. Extracted soil solutions were filtered, first through a filter pa- 
Table 2. Parameters of plant and soil samples for site B (sandy-loam soil)

\begin{tabular}{|c|c|c|c|c|c|c|}
\hline$h$ & Date & Sample & $\mathrm{K}, \mathrm{mg} / \mathrm{g}$ & ${ }^{137} \mathrm{Cs}, \mathrm{Bq} / \mathrm{kg}$ & $\left({ }^{137} \mathrm{Cs} / \mathrm{K}\right)_{p} /\left({ }^{137} \mathrm{Cs} / \mathrm{K}\right)_{s s}$ & $C_{\mathrm{K}}, \mathrm{mg} / \mathrm{cm}^{3}$ \\
\hline 0.0579 & 25.06 .2012 & $\begin{array}{l}\text { Soil solution } \\
\text { Raphanus sativus } \\
\text { Sinapis sp. } \\
\text { Rumex acetosa }\end{array}$ & $\begin{array}{l}0.0108 \\
36.94 \\
37.91 \\
36.17\end{array}$ & $\begin{array}{r}4.4 \\
1729 \\
1904 \\
1513\end{array}$ & $\begin{array}{l}0.115 \\
0.122 \\
0.103\end{array}$ & 0.882 \\
\hline 0.0081 & 01.08 .2012 & $\begin{array}{l}\text { Soil solution } \\
\text { Raphanus sativus } \\
\text { Rumex acetosa } \\
\text { Sinapis sp. }\end{array}$ & $\begin{array}{l}0.0198 \\
45.37 \\
30.26 \\
22.44\end{array}$ & $\begin{array}{l}14.41 \\
2918 \\
2510 \\
2840\end{array}$ & $\begin{array}{l}0.0879 \\
0.114 \\
0.174\end{array}$ & 0.226 \\
\hline 0.050 & 18.09 .2012 & $\begin{array}{l}\text { Soil solution } \\
\text { Raphanus sativus } \\
\text { Rumex acetosa }\end{array}$ & $\begin{array}{l}0.0079 \\
45.8 \\
46.2\end{array}$ & $\begin{array}{r}7.6 \\
4069 \\
4839\end{array}$ & $\begin{array}{l}0.0925 \\
0.109\end{array}$ & 0.557 \\
\hline 0.0716 & 15.05 .2013 & $\begin{array}{l}\text { Soil solution } \\
\text { Rumex acetosa } \\
\text { Elytrigia repens }\end{array}$ & $\begin{array}{l}0.0072 \\
25.46 \\
12.53\end{array}$ & $\begin{array}{l}5.11 \\
8341 \\
4556\end{array}$ & $\begin{array}{l}0.460 \\
0.511\end{array}$ & 0.725 \\
\hline 0.111 & 04.06 .2013 & $\begin{array}{l}\text { Soil solution } \\
\text { Raphanus sativus }\end{array}$ & $\begin{array}{l}0.011 \\
45.45\end{array}$ & $\begin{array}{l}9.15 \\
10763\end{array}$ & 0.285 & 1.73 \\
\hline 0.0178 & 26.06 .2013 & $\begin{array}{l}\text { Soil solution } \\
\text { Elytrigia repens } \\
\text { Lepidium sativum } \\
\text { Rumex acetosa } \\
\text { Convolvulus } \\
\text { Raphanus sativus }\end{array}$ & $\begin{array}{l}0.0208 \\
22.39 \\
31.85 \\
23.38 \\
23.59 \\
29.32\end{array}$ & $\begin{array}{l}14.32 \\
3012 \\
19082 \\
7846 \\
1595 \\
12212\end{array}$ & $\begin{array}{l}0.195 \\
0.870 \\
0.487 \\
0.0982 \\
0.605\end{array}$ & 0.522 \\
\hline 0.0111 & 09.07 .2013 & $\begin{array}{l}\text { Soil solution } \\
\text { Setaria glauca } \\
\text { Coriandrum sativum } \\
\text { Raphanus sativus }\end{array}$ & $\begin{array}{l}\quad 0.020 \\
26.26 \\
14.7 \\
38.16\end{array}$ & $\begin{array}{c}10.62 \\
6944 \\
4311 \\
25099\end{array}$ & $\begin{array}{l}0.498 \\
0.552 \\
1.239\end{array}$ & 0.31 \\
\hline 0.0070 & 20.08 .2013 & $\begin{array}{l}\text { Soil solution } \\
\text { Setaria glauca } \\
\text { Convolvulus } \\
\text { Oenothera rubricaulis } \\
\text { Raphanus sativus }\end{array}$ & $\begin{array}{l}0.0105 \\
19.01 \\
26.88 \\
25.42 \\
21.64\end{array}$ & $\begin{array}{l}\quad 7.43 \\
2636 \\
2263 \\
14577 \\
30145\end{array}$ & $\begin{array}{l}0.196 \\
0.119 \\
0.810 \\
1.969\end{array}$ & 0.1036 \\
\hline
\end{tabular}

per with a pore near $1-3 \mu \mathrm{m}$ in diameter and then through a membrane filter with a pore $0.1 \mu \mathrm{m}$ in diameter (Melior XXI Ltd., Russia). The soil solutions after the filtration were clear (colorless). To conserve the obtained soil solutions, we added nitric acid to them a in a proportion of $1 \mathrm{ml}$ of concentrated nitric acid per $500 \mathrm{ml}$ of the solution and heated it to boiling.

The soil humidity "in situ" $h$ was found with experimental error of $10 \%$, by using a gravimetric technique as a ratio of water mass in the soil sample to the mass of the dried soil. The soil samples were dried in a drying oven at $100{ }^{\circ} \mathrm{C}$. The content of ${ }^{137} \mathrm{Cs}$ in the samples of plants and soil so- lutions was monitored through the activity concentration, which was obtained, by using a HPGe ORTEC GMX40P4-83-RB POPTOP sn.48-TN22465A gamma-spectrometer (AMETEK, USA) with a semiconductor detector. The experimental error, as a rule, did not exceed $10 \%$. The minimal detectable activity for ${ }^{137} \mathrm{Cs}$ was of $0.1 \mathrm{~Bq}$ per a sample for the measuring time of $10^{4} \mathrm{~s}$, the average error was $20 \%$ $(p=0.95)$. The concentrations of potassium in the samples of plants and soil solutions were measured by the atom-absorption technique, by using a S-115M1 spectrophotometer at a wavelength of $766.5 \mathrm{~nm}$ with an error of $5 \%$. The method was described in more details in Ref. [19]. 
Table 3. Parameters of plant and soil samples for site B2 (sandy soil)

\begin{tabular}{|c|c|c|c|c|c|c|}
\hline$h$ & Date & Sample & $\mathrm{K}, \mathrm{mg} / \mathrm{g}$ & ${ }^{137} \mathrm{Cs}, \mathrm{Bq} / \mathrm{kg}$ & $\left({ }^{137} \mathrm{Cs} / \mathrm{K}\right)_{p} /\left({ }^{137} \mathrm{Cs} / \mathrm{K}\right)_{s s}$ & $C_{\mathrm{K}}, \mathrm{mg} / \mathrm{cm}^{3}$ \\
\hline 0.0744 & 04.06.2013 & $\begin{array}{l}\text { Soil solution } \\
\text { Lepidium sativum } \\
\text { Raphanus sativus }\end{array}$ & $\begin{array}{l}0.0131 \\
39.55 \\
39.27\end{array}$ & $\begin{array}{c}19.1 \\
5046 \\
20525\end{array}$ & $\begin{array}{l}0.088 \\
0.358\end{array}$ & 1.38 \\
\hline 0.0119 & 26.06.2013 & $\begin{array}{l}\text { Soil solution } \\
\text { Lepidium sativum } \\
\text { Atriplex patula } \\
\text { Raphanus sativus } \\
\text { Setaria glauca }\end{array}$ & $\begin{array}{l}0.0218 \\
21.74 \\
49.03 \\
117.61 \\
31.33\end{array}$ & $\begin{array}{l}16.95 \\
5055 \\
6690 \\
6380 \\
4990\end{array}$ & $\begin{array}{l}0.299 \\
0.175 \\
0.070 \\
0.205\end{array}$ & 0.368 \\
\hline 0.0042 & 09.07 .2013 & $\begin{array}{l}\text { Soil solution } \\
\text { Setaria glauca } \\
\text { Atriplex patula } \\
\text { Raphanus sativus }\end{array}$ & $\begin{array}{l}0.0168 \\
26.26 \\
53.25 \\
34.96\end{array}$ & $\begin{array}{l}\quad 7.31 \\
4196 \\
7907 \\
8491\end{array}$ & $\begin{array}{l}0.367 \\
0.343 \\
0.562\end{array}$ & 0.0954 \\
\hline 0.0061 & 20.08.2013 & $\begin{array}{l}\text { Soil solution } \\
\text { Setaria glauca } \\
\text { Oenothera rubricaulis } \\
\text { Raphanus sativus } \\
\text { Atriplex patula }\end{array}$ & $\begin{array}{l}0.0139 \\
23.62 \\
25.57 \\
22.76 \\
42.59\end{array}$ & $\begin{array}{l}\quad 3.92 \\
2577 \\
4850 \\
9947 \\
3189\end{array}$ & $\begin{array}{l}0.387 \\
0.673 \\
1.550 \\
0.266\end{array}$ & 0.1204 \\
\hline
\end{tabular}

\section{Results}

The obtained data for the sites B, B2, and D are represented in the Tables $1-3$. We can see the humidity $h$ (ratio of the water mass in the sample to the mass of dried soil), date of sample selection, kind of species, concentrations of potassium and ${ }^{137} \mathrm{Cs}$ in the plants and the corresponding soil solution, selectivity of plant uptake for ${ }^{137} \mathrm{Cs}$ versus potassium $r=\left({ }^{137} \mathrm{Cs} / \mathrm{K}\right)_{p} /\left({ }^{137} \mathrm{Cs} / \mathrm{K}\right)_{s s}$, were $\left({ }^{137} \mathrm{Cs} / \mathrm{K}\right)_{p}$ and $\left({ }^{137} \mathrm{Cs} / \mathrm{K}\right)_{s s}$ - the ratios of concentration ${ }^{137} \mathrm{Cs}$ and $\mathrm{K}$ in the plant and corresponding soil solution, respectively, and the concentration of dissolved potassium in soil (product of the potassium concentration in a soil solution and the content of the soil solution in a unit volume of soil) $C_{\mathrm{K}}$. We can see that $r$ is also the ratio of the concentration coefficients plant/soil solution for ${ }^{137} \mathrm{Cs}$ and $\mathrm{K}$ in the investigated samples. The experimental error for all data does not exceed $10 \%$.

One can see for site D (Table 1 ) with peaty soil that $r$ was close to 1 , when $C_{\mathrm{K}}=2.75 \mu \mathrm{g} / \mathrm{cm}^{3}$ (the highest value). In the cases where $0.5 \mu \mathrm{g} / \mathrm{cm}^{3}<$ $<C_{\mathrm{K}}<2 \mu \mathrm{g} / \mathrm{cm}^{3}, r$ was much less than 1 for most of the plants. For the selection dates of 09.07.2013 and 20.08.2013, when $C_{\mathrm{K}}$ was below $0.5, r$ was much higher than 1 for most of the plants.

For sites B and B2 with, respectively, sandy-loam and sandy soils (see Tables 2 and 3 ), $C_{\mathrm{K}}$ did not exceed $2 \mu \mathrm{g} / \mathrm{cm}^{3}$ in each case. When $C_{\mathrm{K}}$ was below $0.5 \mu \mathrm{g} / \mathrm{cm}^{3}, r$ was higher than that in the cases where $C_{\mathrm{K}}$ was above $0.5 \mu \mathrm{g} / \mathrm{cm}^{3}$. This is especially evident for the selection dates of 09.07.2013 and 20.08.2013.

\section{Discussion}

So, the concentration coefficients plant/soil solution are approximately equal ( $r$ is close to 1) at higher concentrations of dissolved potassium in soil $\left(C_{\mathrm{K}}>2 \mu \mathrm{g} / \mathrm{cm}^{3}\right)$. This implies that the potassium and cesium uptake to the plants occurs by the NSCCs. These data confirm the conclusions of Refs. [15, 16].

As $C_{\mathrm{K}}$ decreases into the range from 0.5 to $2 \mu \mathrm{g} / \mathrm{cm}^{3}$ (potassium deficit), $r$ becomes much less than 1 for all the sites, i.e., the concentration coefficient plant/soil solution for potassium is much higher than that for cesium, whose concentration in plants becomes much times less. The cesium uptake in plants remains approximately proportional to the concentration of cesium dissolved in the soil. Potassium transfers to plant also use a highly selective channel (KIRC). This is also in accordance with the data of Refs. [15, 16].

One can see in the tables that $r$ is high and can significantly exceed 1 at $C_{\mathrm{K}}<0.5 \mu \mathrm{g} / \mathrm{cm}^{3}$. The cesium content in the plants becomes much greater than

ISSN 2071-0194. Ukr. J. Phys. 2018. Vol. 63, No. 3 
that in the previous case. We believe that, as $C_{\mathrm{K}}$ falls below $0.5 \mu \mathrm{g} / \mathrm{cm}^{3}$, plants begin to use one highly selective channel more. This is a $\mathrm{K} / \mathrm{H}$-symporter. The cesium uptake to plants through this channel exceeds that for potassium. Therefore, the ${ }^{137} \mathrm{Cs}$ content in plant increases.

\section{Conclusion}

While the concentration of dissolved potassium $C_{\mathrm{K}}$ in soil exceeds $2 \mu \mathrm{g} / \mathrm{cm}^{3}$, the potassium and cesium uptakes occur through mainly low-selectivity potassium channels (NSCC). The selectivity of the plant uptake for ${ }^{137} \mathrm{Cs}$ versus potassium $r$ is herewith close to 1 . As the concentration of dissolved potassium becomes below $2 \mu \mathrm{g} / \mathrm{cm}^{3}$ but above $0.5 \mu \mathrm{g} / \mathrm{cm}^{3}$, potassium transfers to plants also through a high-selective channel (KIRC). In this case, cesium transfers to plants through the low-selective channel only. Herewith, $r$ is much less than 1 . When $C_{\mathrm{K}}<0.5 \mu \mathrm{g} / \mathrm{cm}^{3}$, plants use one highly selective potassium channel more $(\mathrm{K} / \mathrm{H}$ symporter). The cesium uptake to plants through this channel is rather significant. In this case, $r$ can exceed 1.

This work was supported financially by a grant from The Science and Technology Center of Ukraine (STCU project 5439).

1. P.J. White, M.R. Broadley. Mechanisms of caesium uptake by plants. New Phytol. 147, 241 (2000).

2. Y.-G. Zhu, E. Smolders. Plant uptake of radiocaesium: A review of mechanisms, regulation and application. J. Exp. Bot. 51, 1635 (2000).

3. P.J. White, L. Wiesel, M.R. Broadley. Cation channels and the uptake of radiocaesium by plants. In: Ion Channels and Plant Stress Responses, edited by V. Demidchik, F. Maathuis (Springer, 2010).

4. M.R. Broadley, A.J. Escobar-Gutiérrez, H.C. Bowen, N.J. Willey, P.J. White. Influx and accumulation of $\mathrm{Cs}^{+}$ by the akt1 mutant of Arabidopsis thaliana (L.) Heynh. lacking a dominant $\mathrm{K}^{+}$transport system. J. Exp. Bot. 52, 839 (2001).

5. C.R. Hampton, M.R. Broadley, P.J. White. Short review: The mechanisms of radiocaesium uptake by Arabidopsis roots. Nukleonika 50, S3 (2005).

6. Z. Qi, C.R. Hampton, R. Shin, B.J. Barkla, P.J. White, D.P. Schachtman. The high affinity $\mathrm{K}^{+}$transporter AtHAK5 plays a physiological role in planta at very low $\mathrm{K}^{+}$concentrations and provides a caesium uptake pathway in Arabidopsis. J. Exp. Bot. 59, 595 (2008).

7. J.J. Ayub, R.L. Valverde, M.J. García-Sanchez, J.A. Fernandez, R.H. Velasco. Kinetics of Caesium and Potassium
Absorption by Roots of Three Grass Pastures and Competitive Effects of Potassium on Caesium Uptake in Cynodon sp. World History of Radon Research and Measurement from the Early 1900's to Today, edited by A.S. Paschoa (American Institute of Physics, 2008), p. 269.

8. V. Demidchik, R.J. Davenport M. Tester. Nonselective cation channels in plants. Annu. Rev. Plant Biol. 53, 67 (2002).

9. P.J. White, A.J. Karley. Potassium. In Cell Biology of Metals and Nutrients, edited by R. Hell, R.-R. Mendel (Springer, 2010), p. 199.

10. P.J. White. Improving potassium acquisition and utilisation by crop plants. J. Plant Nutr. Soil Sci. 176, 305 (2013).

11. F.J.M. Maathuis, D. Sanders. Mechanisms of potassium absorption by higher plant roots. Physiol. Plant. 96, 158 (1996).

12. F.J.M. Maathuis, A.M. Ichida, D. Sanders, J.I. Shroeder. Roles of High Plant $\mathrm{K}^{+}$Channels. Plant Physiol. 114, 1141 (1997).

13. C.R. Hampton, M.R. Droadlug, P.J. White. Short review: The mechanisms of radiocaesium uptake by Arabidopsis roots. Nukleonika 50, S3 (2005).

14. S. Fujimura, J. Ishikawa, Y. Sakuma, T. Saito, M. Sato, K. Yoshioka. Theoretical model of the effect of potassium on the uptake of radiocesium by rice. J. Environ. Radioact. 138, 122 (2014).

15. V.V. Prorok, C.F.V. Mason, L.A. Bulavin, L.V. Poperenko. The factors determining channels of Cs-137 and K transfer from soil to plant under natural conditions. In: International Conference Twenty-five Years after Chernobyl Accident. Safety for the Future. April 20-22, 2011, Kyiv, Ukraine. Reports proc. Conclusions and recommendations (Kyiv, 2011).

16. V.V. Prorok, L.A. Bulavin, L.V. Poperenko. Investigation of channels of Cs-137 and K transfer from soil to plant under natural conditions with optical and gamma spectrometry. Ukr. J. Phys. 57, 230 (2012).

17. V.V. Prorok, A.P. Ganushevich, T.I. Makarenko, V.V. Ostashko, L.V. Poperenko, L.Yu. Melnichenko. Strontium and calcium relations in plant and soil solution on Chornobyl affected areas. Ukr. J. Phys. 59, 233 (2014).

18. V.V. Prorok, P.J. White, O.I. Dacenko, L.A. Bulavin, S.E. Zelensky, L.Yu. Melnychenko, S.G. Rozouvan, L.V. Poperenko. Dependence of the concentrations of cesium-137 and potassium in extracted soil solutions on soil humidity before centrifugation. Nuclear Phys. Atom. Energy 18, 87 (2017).

19. V.V. Prorok, O.I. Dacenko, L.A. Bulavin, L.V. Poperenko, P.J. White. Mechanistic interpretation of the varying selectivity of Cesium-137 and potassium uptake by radish (Raphanus sativus L.) under field conditions near Chernobyl. J. Environ. Radioact. 152, 85 (2016).

Received 20.11.17 
В.В. Пророк, О.І. Даценко,

Л.А.Булавін, С.С. Зеленсъкий, Л.В. Поперенко

ОПТИЧНІ ТА ГАММА-СПЕКТРОМЕТРИЧНІ

ДОСЛІДЖЕННЯ МЕХАНІЗМУ НАДХОДЖЕННЯ

КАЛІЮ ТА ЦЕЗІЮ-137 У РОСЛИНИ В ПОЛЬОВИХ

УМОВАХ ПРИ НЕСТАЧІ ВОДИ

$\mathrm{P}$ е $з$ ю м е

Канали надходження ${ }^{137} \mathrm{Cs}$ та калію з грунту в рослини при нестачі води досліджено в польових умовах. Різноманітні рослини швидкого визрівання одночасно вирощувалися і збиралися кілька разів протягом двох сезонів 20122013 рр. на одних і тих самих експериментальних ділянках і з різними типами грунтів при одних і тих самих природних умовах у 10-кілометровій Чорнобильській Зоні Відчужен- ня. Після кожного відбору вимірювався вміст ${ }^{137} \mathrm{Cs}$ та K в рослинах та екстрагованих грунтових розчинах. Калій та цезій надходили до коренів рослин, як правило, через низькоселективні канали, коли концентрація розчиненого калію $\left(C_{\mathrm{K}}\right)$ у грунті перевищувала 2 мкг $/ \mathrm{cm}^{3}$. В цьому випадку селективність надходження в рослину для ${ }^{137} \mathrm{Cs}$ відносно калію $r$ була близька до 1 . Однак коли $C_{\mathrm{K}}$ була в інтервалі від 0,5 до 2 мкг $/ \mathrm{cm}^{3}$, калій, як виявилося, також надходив до коренів рослин через високоселективні калієві канали, тоді як цезій надходив до коренів лише через низькоселективні канали. В цьому випадку величина $r$ була набагато меншою від 1 . Коли ж $C_{\mathrm{K}}$ була нижчою за $0,5 \mathrm{мкг} / \mathrm{cm}^{3}$, цезій та калій надходили до коренів через конкуруючі канали з більшою селективністю для цезію, ніж для калію. Значення $r$ у цьому випадку могло перевищувати 1. 